\title{
EDUCATION, CULTURE AND REGIONAL DEVELOP- MENT: REFLECTIONS ON THE CREATIVE ECONOMY
}

\author{
Received on: $10 / 10 / 2018$ \\ Approved on: 01/11/2018 \\ Michele Lins Aracaty E Silva ${ }^{1}$ \\ Marcela Fróes Da Costa ${ }^{2}$
}

\begin{abstract}
The creative economy or knowledge economy (new economy) has been the object of public policies focused on creativity in order to generate opportunities and employment and income. Based on this worldwide phenomenon, this research aims to study the Creative Economy in Manaus from 2010 to 2015 , based on the analysis of the main creative segments found (Cultural Expressions, Music, Biotechnology and $R \& D$ ), and besides pointing out the main programs and actions aimed at the promotion of these creative segments. For that, a bibliographic study of scientific articles and books was done, as well as the documentary study, through the Mapping of Brazilian Creative Industries with data provided by FIRJAN (2016). In addition, the observational method was used in which the behavior of the economic variables of the creative indicators, which are: level of qualification and distribution by gender, geographical location and local investment, total of professionals in the labor market and average salary were analyzed methodically. The study presented the characteristics of each creative segment based on the creative indicators and their variables, thus, determining their behavior in the proposed period, (the highest levels of professional growth in the labor market, levels of salaries, qualification and how is the distribution by gender)
\end{abstract}

KEYWORDS: Creative Economy. Manaus. Creative Segments. Programs and Actions.

\footnotetext{
$1 \mathrm{PhD}$ in Regional Development from the University of Santa Cruz do Sul (UNISC). Master degree in Regional Development by the Federal University of Amazonas (UFAM). GRADUATE in Economic Sciences by the Federal University of Amazonas (UFAM). It is from the faculty of the Federal University of Amazonas - UFAM. E-mail: michelearacaty@yahoo.com.br

2 Administrator, graduated from Literatus Faculty (UNICEL - 2011). Executive MBA in Marketing (GALILE) and Specialist in Teaching in Higher Education (UNIASSELVI) and Distance Education: Management and Tutoring. Member of the Research Group on Public Policies - PPGE / UFAM. Currently Professor - External Tutor in Institutions of higher education (Federal University of Amazonas CED / UFAM, UNIASSELVI, Faculty of Anhanguera), in the courses of Bachelor in Administration; Technologist in Human Resources; and Technologist in Marketing and Management Processes; Full time, masters Degree in Public Management.E-mail: marcefroes@gmail.com
} 


\section{INTRODUCTION}

The Creative Economy is becoming one of the main dynamic sets of productive activities in the world, named as a new economy or knowledge economy, aiming the search for new types of work and social welfare. This process is directly associated with changes in the world economy in the last century, where countries perceived a new form of economic development in this new economy. This new view has broadened the interest of several authors such as: Ostrower (1986) on creativity and the process of creation, Scott (1999) on cultural cities, Caves (2000) on the system of creative production and its importance in economics, Throsby (2001) on the relationship of economics to culture, Florida (2002) on creative classes and Howkins (2001) on how people make money from ideas.

The Creative Economy has as its raw material the creativity, including activities related to design, fashion, architecture, arts, cultural production, cinema, tourism, media, and others. The World Bank estimated that the creative industries together, represented $7 \%$ of global employment and 10\% annual growth between 2000 and 2005 .

Countries like the United Kingdom, China and the United States of America (USA), which are great world powers, adopt the Creative Economy as part of their economy. Brazil began work on this new economy starting in 2004. For example, from projects of entities such as the Brazilian Micro and Small Business Support Service (SEBRAE), the Institute of Applied Economic Research (IPEA) and the Federation of Industries of Rio de Janeiro (FIRJAN) that started to develop research and programs related to the sector.

In 2015, the Brazilian creative industries generated a GDP equivalent to $\mathrm{R} \$ 155.60$ billion or $2.64 \%$ of all that is produced in the national territory, placing the country in the ranking of the five largest producers of creativity in the world. Among the Brazilian states that stand out in this new sector are: Rio de Janeiro, São Paulo, Santa Catarina, Rio Grande do Sul, Ceará and Amazonas.

Specifically in Manaus, the Creative Economy grows gradually from the evolution of its main segments, which are: Biotechnology, due to the exuberant local biodiversity, propitiating greater profitability to the segment. As an example, it is mentioned that the value of the salary paid in the area is almost the double of the base salary in relation to the other Brazilian capitals. In Music, an evolution of the salaries of the instrumental musicians was registered; In Research and Development (R \& D), the highlights are the IT industries, belonging to the Industrial Pole of Manaus (PIM), and finally, Cultural Expressions that are related to all aspects such as - crafts, gastronomy and popular festivals - that present themselves in the capital in forms of fairs, gastronomic meetings and presentations in the squares around the city.

\section{THEORETICAL FOUNDATION}

\subsection{Creative Economy and Creative Industry: Origin and Development}

The current transformation of the industrial society originates from the change in the economy style of production. Before, based on mass production, it used capital and intensive work, altering itself to an economy based on the use of intellectual capital, that is, the use of the creative Knowledge (creativity) of the individual (OSTROWER, 1986).

Creativity is the raw material of the creative economy (COSTA; SOUZA, 2011). Its definition concerns not only creating the new, but also reinventing, thus, obtaining solutions to new and old problems. In other words, creativity is the use of ideas to produce new ideas (UNCTAD, 2010). 
The scientific studies on the "creative industries" base of the creative economy emerge at the end of the twentieth century, from the publication of the book Creative industries: Contracts between art and commerce by Richard Caves. From there, other publications of great importance arose as: The creative Economicy: how people make 21 money from ideas, by John Howkins, in 2000-the author is considered the "father" of the creative economy-for him, "creativity is the ability to generate something new". (HOWKINS, 2001, p. 01, own translation); the rise of the creative class, by Richard Florida, in 2002. Other authors also stood out in the studies of this new "industry": Landry (2000), Throsby (2001), Leadbeater (2004) and Pratt (2009).

Creative industries are those that have their origins in individual creativity, skill and talent and that present a potential for the creation of wealth and jobs through the creation and exploitation of intellectual property. (Kings, 2007, p. 16, own translation).

For Caves (2000), creative industries are those related to arts, culture and entertainment in general. Its field of study corresponds to the activities of cinema, photography, music, scenic and visual arts, radio and television and handcrafts.

According to UNCTAD (2010), the creative industries are divided into four large groups and nine subgroups presented below in table 1 :

\begin{tabular}{|c|l|}
\hline GROUPS & \multicolumn{1}{c|}{ SUBGROUPS } \\
\hline Patrimony & $\begin{array}{l}\text { Traditional Cultural Expressions: handicrafts, festivals and celebrations; } \\
\text { Cultural places: Archaeological sites, museums, libraries, exhibitions, etc. }\end{array}$ \\
\hline Arts & $\begin{array}{l}\text { Visual arts: Paintings, sculptures, photography and antiques; } \\
\text { Performing Arts: Live music, theatre, dance, opera, circus, puppet theatre, etc. }\end{array}$ \\
\hline Media & $\begin{array}{l}\text { Publishers and printed media: books, press and other publications; } \\
\text { Audiovisuals: Movies, television, radio and other broadcasts. }\end{array}$ \\
\hline $\begin{array}{c}\text { Functional } \\
\text { Creations }\end{array}$ & $\begin{array}{l}\text { Design: Interiors, graphic, fashion, jewellery, toys; } \\
\text { New media: Software, video games, creative digital content; } \\
\text { Creative Services: Architecture, advertising, cultural and recreational, research and de- } \\
\text { velopment (R\&D) creative, other creative digital services. }\end{array}$ \\
\hline
\end{tabular}

Table 1 - Groups e Subgroups of Creative Industries.

Source: Own Elaboration with UNCTAD data (2010).

As presented before, the creative industries have a wide dynamism, showing the diverse faces of the creative sectors. These sectors involve traditional activities such as crafts and cultural sites, more technological activities such as software creation, research in R\&D and other digital creative services.

The earliest records of the Creative Economy concept originate in the term "creative industries" inspired by the Creative Nation project developed by the Australian government in the early 1990s (CUNNINGHAM, 2002).

Since 1997, the creative economy gains greater visibility, since, Britain's prime Minister Tony Blair includes this new "industry" on his government platform due to the fierce scenario of economic competition on a global scale (REIS, 2008a).

According to UNCTAD (2010), the concept of Creative Economy is summarized as: It is based on creative assets with the potential to create economic growth and development; stimulates income generation, job creation and export revenue while promoting social inclusion, cultural diversity and human development; at the heart of the Creative Economy are the creative industries. 


\subsection{Creative Economy in the world}

Today, the creative economy is one of the most growing sectors in the world economy. It is one of the most profitable areas in terms of profit generation, jobs and exports of goods and services (PASQUALUCCI, 2016). The main factors responsible for the extraordinary growth of the creative industries in the world are the increase of the intellectual capital, the new technology and the modernization in the forms of work. (SEC, 2012).

According to UNCTAD (2010), between 2000 and 2005, the international trade in creative goods and services grew at the annual rate of $8.7 \%$, which caused the total value of exports to reach US $\$ 424$ billion in 2005 , or $3.4 \%$ of world trade. The countries that have the most expressiveness in the creative economy sector are: United Kingdom, China and USA. Some data will be presented below. (SEBRAE, 2016).

\begin{tabular}{|c|l|}
\hline COUNTRY & \multicolumn{1}{c|}{ SEGMENT INFORMAITON } \\
\hline $\begin{array}{c}\text { United King- } \\
\text { dom }\end{array}$ & $\begin{array}{l}\text { There are records of the emergence of the concepts of industry and creative economics } \\
\text { and of the first sector-specific policies (MADEIRA, 2014). } \\
\text { Researchers found that creative industries grew faster than other segments of the } \\
\text { economy and generated new jobs. } \\
\text { Data from 2003 records that CE has contributed more economically than all financial } \\
\text { sectors. Newbigin (2010). } \\
\text { The thirteen sectors identified were: handcrafts, architecture, performing arts, Cinema, } \\
\text { Design, Editorial, fashion, music, advertising, software, interactive leisure software (vid- } \\
\text { eo games) television and radio. }\end{array}$ \\
\hline China & $\begin{array}{l}\text { According to UNCTAD (2010), China represented by the city of Shanghai, was the pio- } \\
\text { neer in the access of the creative industries, with the municipal government playing a } \\
\text { key role. }\end{array}$ \\
\hline $\begin{array}{c}\text { United States } \\
\text { of America } \\
\text { (USA) }\end{array}$ & $\begin{array}{l}\text { One of the largest producers of creative industries in the world and consequently the } \\
\text { largest creator of jobs in this sector. } \\
\text { Since 1996, international sales of cultural products (films, books, music, television pro- } \\
\text { grams and software) have represented the first export sector in the United States, with } \\
\text { a volume of more than } 60 \text { billion dollars. } \\
\text { In 2007, the creative industries were responsible for 6.4\% of the North American econ- } \\
\text { omy, creating foreign sales and exports of \$125.6 billion, one of the sectors with the } \\
\text { highest export in the American economy. (UNCTAD, 2010, p. 60). }\end{array}$ \\
\hline
\end{tabular}

Table 2 - Creative Economy: United Kingdom, China and USA.

Source: Search Data

\subsection{Creative Economy in Brazil}

In Brazil, the creative economy developed in the beginning of the 21st century, in 2004, during the quadrennial meeting of the Unctad in Sao Paulo, the thematic session "High Level Panel on Creative Industries and Development" (REIS, 2008b).

According to FIRJAN (2016), from the perspective of production in Brazil, the creative industry is made up of 239 thousand companies, according to data from 2015. Comparing with 2004 , there was an increase of almost $70 \%$. Still according to FIRJAN (2016). About the demand, there was an increase in the number of creative professionals from 469.8 thousand in (2004) to 851.2 thousand professionals (2015), representing an increase of almost $90 \%$.

One of the most important events of the creative economy in Brazil was the nomination of Brazilian Edna dos Santos-Duisenberg for the leadership of the program of economics and creative industries of the United Nations for Trade and Development (UNCTAD). In Figure 1, the principles that constitute the Brazilian creative economy are presented. 


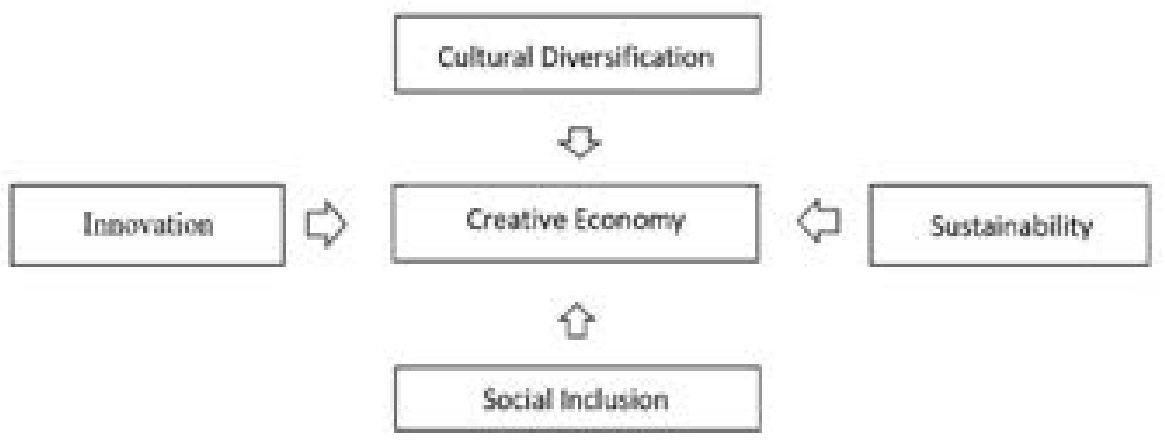

Figure 1 - Guiding principles of the creative economy in Brazil.

Source: FIRJAN (2016)

The FIRJAN Report (2016, page 7) emphasizes among the creative areas: Consumption (44.2\%) and Technology (36.8\%), which accounted for more than $80 \%$ of creative workers in Brazil. Focus on $R \& D, I C T$, Advertising and Architecture.

About public policies aimed at this segment, in 2011 the Secretary of the Creative Economy (SEC), under the Ministry of Culture, was created. It emerged from the National Cultural Plan (PNC), mainly for characterizing the process of institutionalization of cultural public policies and for the support of President Lula in his eight years of government (LEITÃO, 2012).

SEC divided the development of the Creative Economy in both macroeconomic and microeconomic vectors with different axes of action. The macroeconomic consists of the axes of creative territories, studies and research and the legal framework. In addition, the microeconomic consists of the axes of entrepreneurship in creative sectors, from training to creative skills and from networks.

\subsection{Creative Economy in Amazonas}

The creative economy develops in a stronger way in places that have great cultural diversity, artistic expressions, intellectual capital and creative potential.

FIRJAN's mapping Data (2014) shows that the creative economy in Amazonas has developed specially in three creative nuclei: consumption, culture and Technology. Moreover, its segments are, respectively: architecture, music, R\&D, ICT and biotechnology.

According to Sebrae-AM (2016), only $30 \%$ of the total registered enterprises make up the Creative Economy segment in Amazonas, the other $70 \%$ registered are from companies from traditional segments.

Brazilian Ministry of Culture with the Federal University of Amazonas in November 2013, created the Observatory of the Creative Economy of the State of Amazonas (Obec-AM) (UFAM, 2013). The Observatories are research units in charge of the systematization, production and analysis of information and data on the Creative Economy of each State of the Federation and the Federal District (BRASIL, 2013).

\section{METHODOLOGY}

The methodology used is the observational method, characterized as a descriptive, bibliographic and documentary study, using the mapping of the creative industry in Brazil carried out by FIRJAN, (2016), from materials Published on the subject, and presenting a qualitative and quantitative approach in the presentation of the Results. It is possible to realize the growth of the creative 
economy in Manaus in the period from 2010 to 2015; the data is available in tables and graphs in order to express the behavior of the creative segments from their professionals and the Variables.

\section{ANALYSIS AND DISCUSSION OF RESULTS}

From the historical survey carried out in the theoretical reference, it is important to discuss the performance of the creative economy in the local economy (Manaus), the indicators and the variables that make it possible to develop the study on the creative economy in the course of the years proposed for the analysis (2010 to 2015). For a better understanding of the analysis and results, the data will be presented in the forms of tables and graphs to express the participation of the creative segments (cultural expressions, music, Biotechnology and Research \& Development).

The indicators are: human capital, urban environment, productive economic structure, and its variables are respectively: level of qualification and distribution by gender, geographical location and local investment, total Professionals in the market and work plus average salary.

\subsection{Cultural Expressions}

Cultural expressions are ways in which people or groups present certain knowledge or culture, using activities and artistic manifestations that have a meaning for local Identity. Examples of cultural expressions: handicrafts in general, popular fairs and gastronomy.

Formed from a wide and deep mix of indigenous, European and Brazilian Northeastern cultures, Manaus culture presents special regional aspects. The population shows a strong western formation, despite the traditions and behavior filled with legends, beliefs coming from the Indigenous. Located geographically in one of the largest forests in the world, the activity of creating handicrafts uses the resources of the forest itself as jute, mauve, fruit pits and fruits and timbers for the production.

The Paço Fair, gather in each edition around 200 professionals of the Creative Economy. It is located in the historic center of Manaus and its editions happen on the second Sunday of each month or on commemorative dates.

The Eduardo Ribeiro Fair has existed for 17 years in the city; it always happens on Sundays and currently attends 60 families registered in AFAPA. It is the largest handicraft fair in the city and the most Visited. The fair consists of seven sectors distributed: food; bed, table and bath; Clothes and footwear; Marquetry ${ }^{1}$ and indigenous arts and decorations; Children's arts; Jewelry arts and accessories in leather.

Seeking the creation of entrepreneurship in the city, several courses focused on the handicrafts are taught by the prefecture of Manaus along with the Department of Solidarity Economy of the Municipal secretariat of work, Employment and development (Semtrad) and with the Amazonas handicraft Cooperative (Copamart) provide the startup and specialization in the field.

The Social Service of Commerce - AM (SESC-AM) also contributes to entrepreneurship since it promotes, every month, artist exhibitions for the public. The Moacir de Andrade gallery located in the SESC Centro unit, hosts artists and handicraft exhibitions.

Manauara gastronomy is remarkable throughout the country, since the fruit, fish, drinks and spices found in the region instigate everyone who try them.

In the last few years, several ventures emerge in the city focused on gastronomy, such as restaurants, food trucks, food bikes from various gastronomic branches. In addition to local food, mexican, italian, japanese, American and other foods are in city, showing the gastronomic diversity that is settling in Manaus. 
In addition to the offer of food from various cultures, private institutions, aiming to strengthen the interaction between the enterprises and the local public, often organize fairs and gastronomic meetings.

In this context, a gastronomic highlight in Manaus is the "Urban Chef". Considered the largest gastronomic meeting of the city, it aims to offer a globalized and accessible food to the public. In its first edition in 2015, there were more than 30 establishments among restaurants, food trucks and food bikes gathered in one place and a public of more than 15 thousand people in the days of exhibition. In addition, typical fairs of states and regions, for example, cuisine from the State of Pará, Brazilian northeastern cuisine and others are held in the main points of the city.

The main professions focused on the cultural expression segment in Manaus are: artisan, chef, confectionary chef and bar chef, observed in table 1 :

Table 1 - Main professions in the cultural expression segment in Manaus

\begin{tabular}{ccccccc}
\hline Professions & $\mathbf{2 0 1 0}$ & $\mathbf{2 0 1 1}$ & $\mathbf{2 0 1 2}$ & $\mathbf{2 0 1 3}$ & $\mathbf{2 0 1 4}$ & $\mathbf{2 0 1 5}$ \\
\hline Chef & 155 & 176 & 60 & 102 & 127 & 187 \\
Bar Chef & 32 & 54 & 75 & 80 & 77 & 72 \\
Confectionary Chef & 6 & 9 & 10 & 11 & 11 & 23 \\
Artisan & 140 & 132 & 125 & 112 & 97 & 100 \\
\hline
\end{tabular}

Source: FIRJAN (2016)

The profession of artisan appears in descending numbers, most likely, by the lack of regularization of the professionals in the Law. Most of these professionals are working in an irregular way in the Capital squares.

During the period from 2010 to 2015 , one can observe the visible growth in the profession of chef, bar chef and confectionary chef showing that gastronomy is the main area of cultural expressions in the Capital. (Chart 1).

The supply of labor focused on the gastronomy, reflected directly the total of professionals of the segment that had an increase of 39.18\% from 2010 to 2015. In 2010, there were 222 professionals, in 2011, this number passed to 268 professionals. In 2012, it presented a decrease to 179 professionals. In 2013, it grew again, reaching a total of 242 professionals. In 2014, the total number of professionals reached 257 . And finally in 2015 , the total number of professionals increased significantly reaching 309.

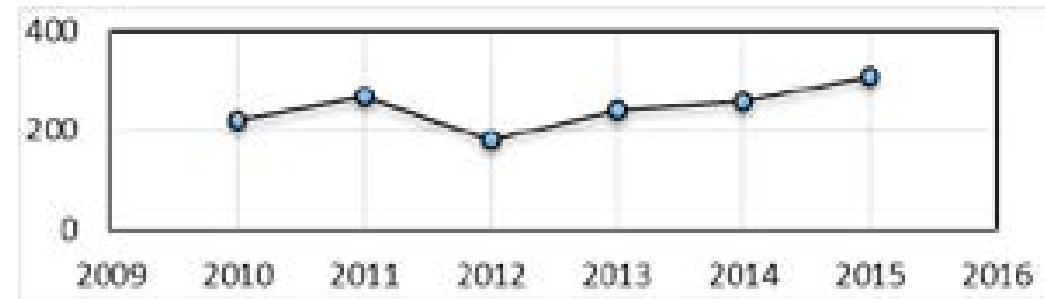

Chart 1 - Total professionals in the segment of cultural expressions - Manaus Source: FIRJAN (2016)

The increase in the total number of professionals in the segment had an impact on the value of wages. In 2010 it was $R \$ 1,471.57$. In 2011, it increased to $R \$ 1,505.57$, an increase of $2.3 \%$ over the previous year. In 2012 , there was an increase to $R \$ 1,627.63$ in percentage numbers, it is an increase of $8.10 \%$ over the previous year. In 2013, the largest increase in the average salary of the period, $R \$ 1,694.73$, in percentage numbers, it was an increase of $4.12 \%$ over the 
previous year. In 2014, there was a reduction of the average salary to $R \$ 1,660.11$, a decrease of $2.04 \%$ over the previous year. Finally, in 2015 the reduction rate was maintained and the average salary reached $R \$ 1,635.25$, a decrease of $1.50 \%$. Although it decreased in the last two years, the average wage accumulated an increase of $11.12 \%$ from 2010 and 2015 . The evolution data can be seen in chart 2, below:

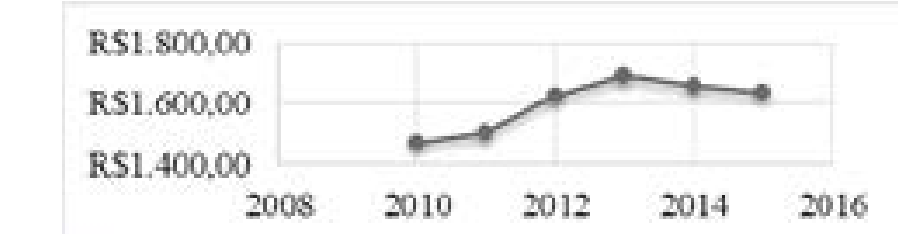

Chart 2 - Avarage Salary in the Segment of Cultural Expressions - Manaus. Source: FIRJAN (2016)

Regarding the gender distribution, there is an equality between female and male professionals, in 2010 and 2011, female professionals were the majority, in 2012, this changed, and male professionals reached the level of 56,40\% over the female, in 2013 and 2014, a certain equality was reflected among professionals in both genders and was maintained until 2015.

As the professions related to gastronomy are predominant located in the Capital, the educational level is mostly College Education, showing that to carry out the job, a specialized workforce is required, as observed in chart 3.

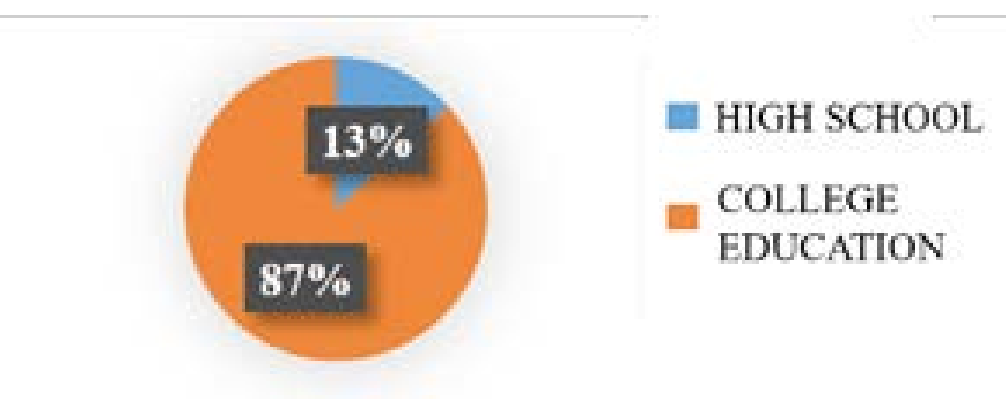

Chart 3 - Education Level in the segment of cultural expressions - Manaus.

Source: FIRJAN (2016)

\subsection{Music}

Music is considered one of the human expression with plurality and wealth. It is the artistic expression most present in people daily life, present in all social classes, of any city and consumed by different age groups.

Manaus is one of the capitals in which the music segment is very influential, due to the great artistic wealth coming from the cultural origin of Manaus society, standing out professionals from multiple fields like composers, musicians in general, technicians, producers, entrepreneurs, and others.

The biggest music reference in the city is the Amazonas opera Festival (FAO), definitively placing the Capital on the route of national and international lyrical Performances. The festival receives support and financial contribution from the Government of the state of Amazonas, in the last three years has been receiving private Investment. Music presentations are also part of SESC-AM's cultural programming. The Project Canção da Mata was created in 2006 by SESC, aiming to show the musical diversity of the capital and to highlight the production of local artists. 
The University of the State of Amazonas (UEA) presents the music project in which Free-singing and musical initiation courses are available free, only respecting the prerequisites required in the notice made available by the Institution. The main professions focused on the music segment in Manaus, as shown in table 2, are: Instrumentalist Interpreter Musician, Singer Interpreter Musician and Regent Musician.

Table 2 - Main Professions of the Music Segment in Manaus.

\begin{tabular}{ccccccc}
\hline Main Professions & $\mathbf{2 0 1 0}$ & $\mathbf{2 0 1 1}$ & $\mathbf{2 0 1 2}$ & $\mathbf{2 0 1 3}$ & $\mathbf{2 0 1 4}$ & $\mathbf{2 0 1 5}$ \\
\hline Instrumentalist Interpreter Musician & 566 & 458 & 197 & 166 & 168 & 136 \\
Singer Interpreter Musician & 17 & 19 & 20 & 25 & 25 & 68 \\
Regent Musician & 5 & 8 & 6 & 14 & 33 & 35 \\
\hline
\end{tabular}

Source: FIRJAN (2016)

As we can see, the period from 2010 to 2015, there was a growth in the number of professionals in the music segment: musician, singer and regent musician, this growth comes from the separation of these two areas: singing and regency. In the same period, there was a sharp drop in the number of instrumentalist musician professionals, reaching in 2015, and a drop of almost $76 \%$.

This abrupt drop in the profession of instrumental interpreters interfered directly in the total of professionals in the segment, that suffered a drop of $59.16 \%$. In 2010, they were 595 professionals. In 2011, this number fell to 494 professionals. In 2012, they were 230 professionals. In 2013, the number of professionals reached the lowest index, 214. In 2011, a slight growth occurred to 238 professionals. and finally, in 2015, there was a tiny growth to 243 professionals. Chart 4 demonstrates data evolution:

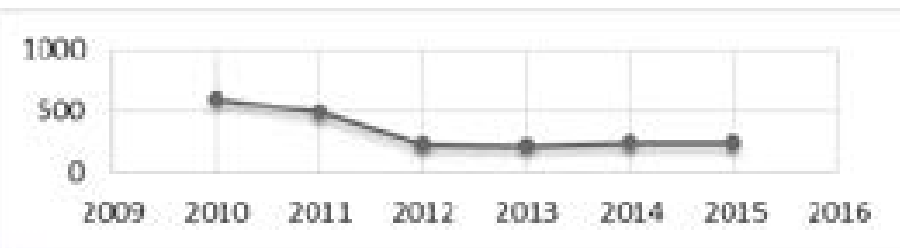

Chart 4 - Total Professionals of the Music Segment - Manaus. Source: FIRJAN (2016)

This drop in the total number of professionals also led to a drop in the average salary, as shown in chart 8. In 2010, the average salary was $R \$ 5,662.39$. In 2011 it passed to $R \$ 5,652.86$, a drop of $0.17 \%$ compared to the previous year. In 2012 , it passed to $R \$ 5,604.36$, a drop of $0.86 \%$ compared to the previous year. In 2013 , the average salary reached $R \$ 4,972.89$, a drop of $11.26 \%$ compared to the previous year. In 2014 , the average salary passed to $R \$ 4,662.96$, a drop of $6.24 \%$ compared to the previous year. And finally, in 2015, it reached R\$4.660,12, a 17.71\% reduction of 2010 to 2015.

About the education degree, most professionals have complete college education; however, there are professionals with high and elementary school in the segment, as shown in chart 5. 


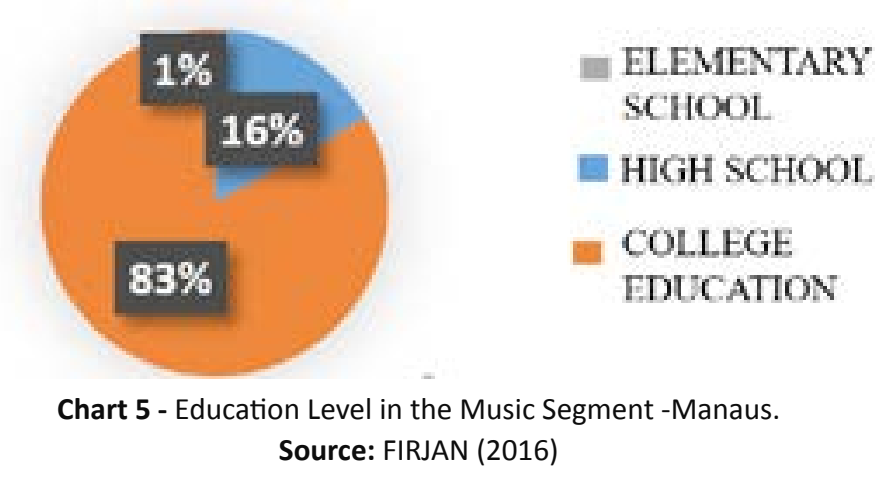

Regarding gender, it is evident the constant growth of male professionals in this Segment. This growth is totally related to the main professions in the capital, since they are mostly due to the national culture of masculine nature.

\subsection{Biotechnology}

Biotechnology is the body of knowledge that allows the use of biological agents to obtain or secure services. It is the most profitable segment in Manaus, since the Capital is at the center of the greater Brazilian biodiversity. Considering this favorable situation, the Amazon Biotechnology Center (CBA) was created in Manaus, whose mission is to promote technological innovation of processes and products, encouraging and creating the basic conditions to support the development of industrial activities based on the sustainable exploitation of amazon biodiversity.

SUFRAMA is responsible for the center, being the main sponsor, approximately $70 \%$ of the financial contribution. The State Government participates in the project through a partnership between FAPEAM and SUFRAMA.

The biotechnology segment presents several professional segments, in Manaus, the most important ones are: Biologist, Biomedical, Environmental Biology researcher, Microorganisms and Parasites researcher, as shown in table 3 below:

Table 3 - Main professions in the biotechnology segment in Manaus

\begin{tabular}{ccccccc}
\hline Main Professions & $\mathbf{2 0 1 0}$ & $\mathbf{2 0 1 1}$ & $\mathbf{2 0 1 2}$ & $\mathbf{2 0 1 3}$ & $\mathbf{2 0 1 4}$ & $\mathbf{2 0 1 5}$ \\
\hline Biologist & 47 & 58 & 60 & 60 & 53 & 47 \\
Environmental Biology Researcher & 48 & 51 & 49 & 40 & 39 & 36 \\
Microorganisms and Parasites Reseacher & 33 & 33 & 29 & 29 & 30 & 28 \\
Biomedical & 2 & 4 & 4 & 7 & 9 & 18 \\
\hline
\end{tabular}

Source: FIRJAN (2016)

As we can observe, there was an increase in the biomedical profession in the period from 2010 to 2015, while the professions of Biologist, Environmental Biology Researcher and Microorganism and Parasites Researcher presented decrease during the same period.

When it is considered that all professions require a greater level of knowledge, the level of education of all professionals is College Education.

In relation to the evolution of the number of professionals in this segment, it was observed that: the total of professionals decreased $4.76 \%$ between 2010 to 2015. In 2010, the total number of professionals were 147. In 2011, there was a growth to 170 professionals. In 2012, a decrease to 145 professionals occurred. In 2013, the total number of professionals reached 141 . 
In 2014, the number of professionals presented their lowest index, 137. Finally, in 2015 , the total number of professionals were 140 . The chart below shows the data evolution:

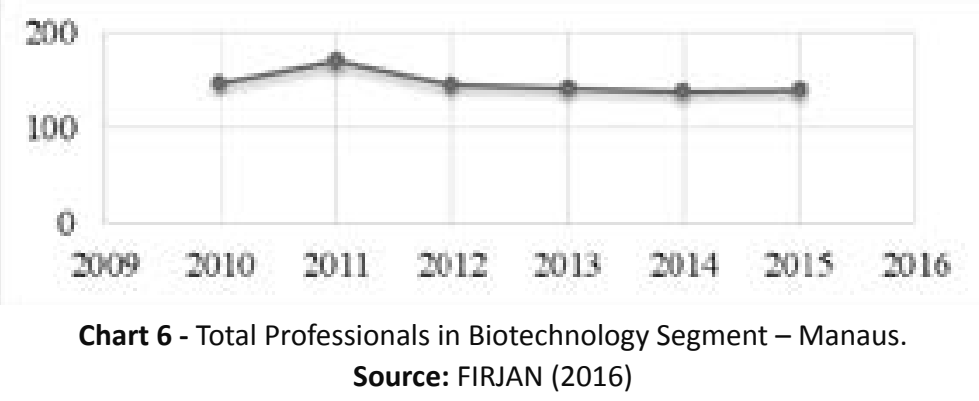

This decrease in the total number of professionals reflected in the average salary value, characterized a drop of $14.13 \%$ from 2010 to 2015. In 2010, it was $\mathrm{R} \$ 14.222 .48$. In 2011, it passed to $\mathrm{R} \$ 12,329.77$, which was a drop of $13.30 \%$ compared to the previous year. In 2012 , there was a slight growth of $5.04 \%$ compared to the previous year, raising the average salary to $R \$ 12,952.42$. In 2013 , the growth of the average salary remained in $\$ 13,409.64$, in percentage it was a growth of $3.52 \%$ compared to the previous year. In 2014 , there was a drop of $1.47 \%$, compared to the previous year in the average salary, and the value was $R \$ 13,211.22$. Finally, in 2015 , the lowest average salary level $R \$ 12,213.24$ was noticed. In Chart 7, the data presented can be checked.

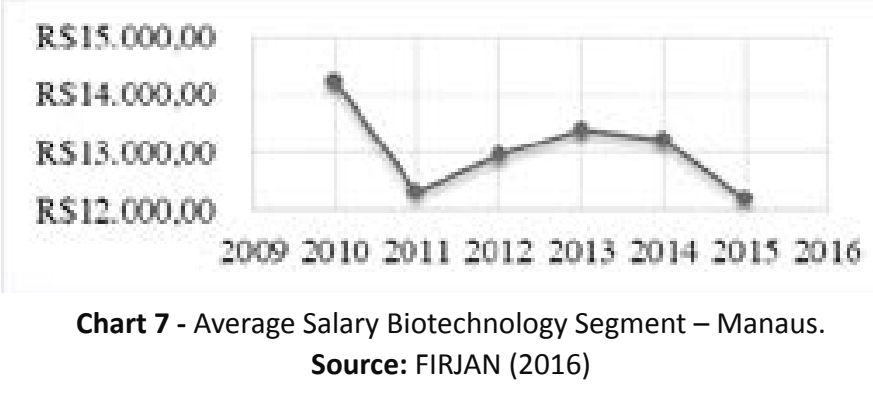

In 2010 and 2011, the segment was mostly composed of male professionals; from 2012, this situation has changed. In 2010 and 2011, male professionals were the majority in the labor market of this segment. In 2012, there was a growth of female professionals, and this growth was consolidating over the coming years. In 2015, it reached 52.9\%, the highest rate of female professionals in the segment.

\subsection{Research \& Development (R\&D)}

Research and Technological Development (R \& D) consists of creative work, undertaken in a systematic way, and its objective is to increase the knowledge base and the use of this knowledge to develop new applications, such as: new or technologically improved products or processes. Such activity has become important in Manaus, due to the industrial pole installed here, where companies seek constant updating of their business, excellence in the execution of their work and their product.

SUFRAMA is responsible for this segment and uses the Information Technology Law in the Amazon to develop it. The law consists in the prerogative that companies producing IT products and services apply, annually, at least 5\% (five percent) of their gross sales in the domestic market in research and development activities in the Amazon region, according to projects developed by themselves. 
The $R$ \& D segment presents several professions, in Manaus the main ones are: Research and Developments Manager, Electrical and Electronic Engineering Researcher and Engineering and Technologies Researcher, as presented in table 4:

Table 4 - Main Professions of the R\&D Segment in Manaus.

\begin{tabular}{cccccccc}
\hline Main Professions & $\mathbf{2 0 1 0}$ & $\mathbf{2 0 1 1}$ & $\mathbf{2 0 1 2}$ & $\mathbf{2 0 1 3}$ & $\mathbf{2 0 1 4}$ & $\mathbf{2 0 1 5}$ \\
\hline Engineering and Technologies Researcher & 141 & 131 & 160 & 116 & 146 & 205 \\
Research and Development Manager & 97 & 101 & 99 & 97 & 104 & 113 \\
Electrical and Electronic Engineering Researcher & 32 & 48 & 47 & 42 & 50 & 54 \\
\hline
\end{tabular}
Source: FIRJAN (2016)

As we can see, the three professions have grown over the years. The profession of engineering and technologies researcher presented the highest growth rate, $45.39 \%$, research and development manager and electrical and electronic engineering researcher grew respectively $16.49 \%$ and $6.8 \%$.

The growth in the number of these professionals reflected directly in the employment level of the segment that had an increase of $20.44 \%$. In 2010, they were 1,835 professionals. In 2011 , they were 2,170 professionals. In 2012, it passed to 2,217 Professionals. In 2013, a drop to 2,199 occurred. In 2014, the number of professionals reached 2,243. Finally, in 2015 , the number of professionals dropped to 2,210 . The data evolution can be verified in the following chart:

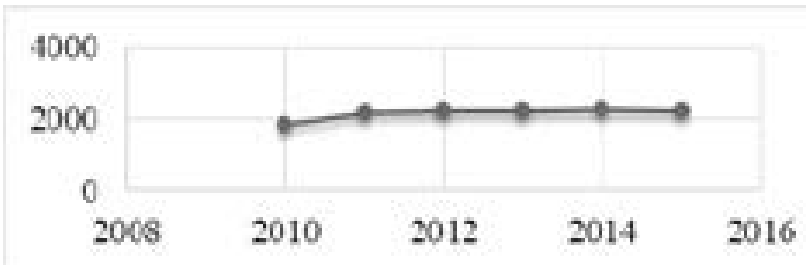

Chart 8 - Total Professionals in the R\&D Segment - Manaus. Source: FIRJAN (2016)

The increase in the number of professionals interfered directly in the average salary of the segment, which increased $15.02 \%$ in the period from 2010 to 2015. In 2010, the average salary was $R \$ 10,049.81$. In 2011 , the average salary increased $11.92 \%$ to $R \$ 11,247.57$. In 2012 , there was a decrease of $0.68 \%$ in relation to the previous year, putting the average salary at $R \$$ $11,170.33$. In 2013 , there was a growth of $0.50 \%$ of the average salary in relation to the previous year, reaching $R \$ 11,226.89$. In 2014 , there was a decrease of $2.26 \%$ of the average salary in relation to the previous year, and it was $R \$ 10,972.27$. Finally, in 2015 , the average salary reached $\mathrm{R} \$ 11,560.10$, a growth of $5.35 \%$ in relation to 2014 , in chart 9 , these changes can be observed:

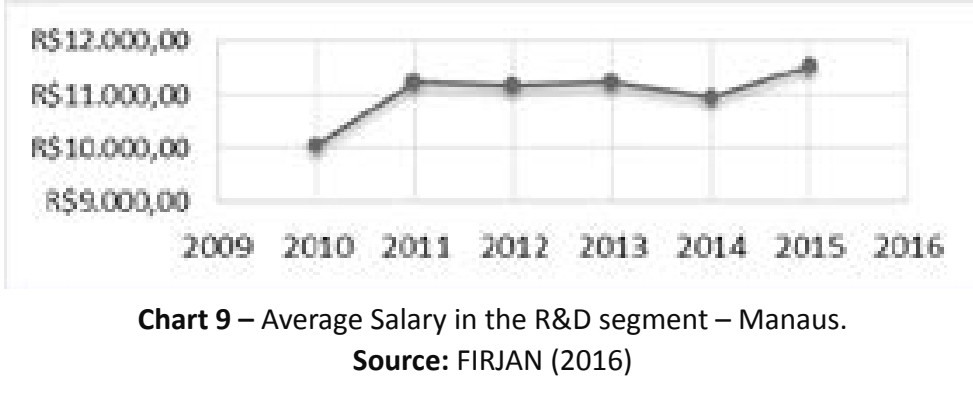


Considering these professions, which require a higher level of professional knowledge and specialization, the level of education is $100 \%$ college education. When it comes to gender, the mastery of the male professional in the labor market of this segment over the years is visible. This masculine domain can be attributed to the work place, mostly, the companies of the Industrial Pole of Manaus.

\section{CONCLUSION}

After the presentation of the main Manaus segments from the economic variables of the creative indicators, it can be seen that at the end of the study, the segment with the highest average salary level was Biotechnology, R \$1.2213.24, followed by R \& D R \$1.1560, 10, Music, $R \$ 4,660.12$ and Cultural Expressions, $R \$ 1,635.25$.

Regarding the total number of professionals, the segments that stood out were: Cultural Expressions and R \& D, which grew $39.18 \%$ and $20.44 \%$ respectively, while in the Music and Biotechnology segments, there was a drop in the employment level of $17,71 \%$ and $14.12 \%$, respectively.

In the R \& D and Biotechnology segments, the level of schooling was presented as a college education degree, while in the Music and Cultural Expressions segments they presented elementary and high school degrees.

About the gender distribution, men mostly compose the music and R\&D segments, while the biotechnology segment is the only one that presented an expressive number of growth of female professionals, since the segment of cultural expressions presented an equality between the professionals, which is the most democratic of the segments analyzed.

Therefore, the creative sector is in fact a segment that is gaining great visibility in every country. The study shows the growth as well as the development of the main creative segments in the proposed period. The results show that the variables of the creative indicators about the sector are correlated, because the variation in one variable affects another and, consequently, has repercussions in the study of the segment and the economy as a whole.

Observing the programs and actions focused on the sector, it is possible to verify the participation of the state, as well as of private entities contributing to the development of the segment, through programs and actions, with emphasis on the segments of Cultural Expressions and music.

In the biotechnology and R\&D segments, all programs and actions focused are SUFRAMA responsibility, in the biotechnology segment, the programs and actions for the sustainable exploitation of Amazonian biodiversity are presented within the center of biotechnology of the amazon, with a partnership with FAPEAM. It is emphasized that the segment of R\&D is connected to the Information Technology law, established by SUFRAMA itself, as a greater form of investment to the Segment. From this, it is stated that the programs and actions focused on the creative segments have leveraged their own growth. 


\section{REFERENCES}

BRASIL. Ministério da Cultura. SEC Inaugura o primeiro Observatório Estadual de Economia Criativa, Brasília, 2013. Disponível em:< em:17 jan. 2017.

CAVES, R. E. Creative Industries: Contracts between art and commerce. Cambridge: Harvard University Press, 2000.

COSTA, A.; SOUZA, E. Economia Criativa: novas oportunidades baseadas no capital intelectual. Economia \& Tecnologia, Curitiba, ano 7, v. 25, p. 179-186, abr./jun., 2011.

CUNNINGHAM, S. D. From cultural to creative industries: theory, industry, and policy implications. Media international Australia incorporating culture and policy. Quarterly journal of media research and resources, n. 102, p. 54-65, 2002.

FIRJAN. Mapeamento da Industria Criativa no Brasil. Rio de Janeiro: SISTEMA FIRJAN, 2016.

FLORIDA, R. A ascensão da classe criativa. Tradução: Ana Luiza Lopes. Porto Alegre, RS: L\&PM, 2002.

HOWKINS, J. The creative economy: how people make money from ideas. London: Penguin Press, 2001.

LANDRY, C. The creative city: a toolkit for urban innovators. London: Earthscan Publications Ltd, 2000.

LEADBEATER, C. Britain's Creative Challenge. Creative and Cultural Skills, 2004.

LEITÃO, C. Plano da Secretaria de Economia Criativa: políticas, diretrizes e ações 2011-2014. 2. ed. Brasília: Minc, 2012.

MADEIRA, M. G. Economia Criativa: implicações e desafios para a política externa brasileira. Brasília: FUNAG, 2014.

NEWBIGIN, J. A. Economia Criativa: Um guia Introdutório. Reino Unido: British Council, 2010.

OSTROWER, F. Criatividade e processos de criação. 5. Ed. Petrópolis, RJ: Vozes, 1986.

PASQUALUCCI, D. A economia Criativa no mundo Moderno. São Paulo, 2016. Disponível em: <https://www.linkedin.com> Acesso em: 20 abr. 2017.

PRATT, A. Urban Regeneration: From the Arts "Feel Good" Factor to the Cultural Economy: A Case Study of Hoxton. London, Urban Studies, v. 46, n. 5-6, p. 1041-1061, 2009.

REIS, A. C. Cultura e Economia Criativa. São Paulo: Itaú Cultura, 2007.

- (Org.). Economia Criativa: como estratégia de desenvolvimento: uma visão dos países em desenvolvimento. São Paulo: Itaú Cultural, 2008a.

Transformando a Criatividade Brasileira em Recursos Econômicos. São Paulo: Itaú Cultural, 2008b.

SCOTT, A. The cultural economy: geography and creative field. In: MEDIA CULTURE E SOCIETY. 
London: Thousand Oaks and New Delhi, v. 21, p. 807-817, 1999.

SEBRAE. O que é a Economia Criativa, Brasília, 2016. Disponível em: < http://www.sebrae.com. br>. Acesso em: 10 jan. 2017.

SECRETARIA DA ECONOMIA CRIATIVA. Relatório de Economia Criativa 2010: Economia Criativa uma, opção de desenvolvimento. - Brasília: /São Paulo: Itaú Cultural, 2012. 424 p.

THROSBY, D. Economics and culture. United Kingdom: Cambridge University Press, 2001.

UFAM. UFAM inaugura o primeiro observatório de Economia Criativa do Brasil. Manaus, out ,2013. Disponível em: < http://www.ufam.edu.br> Acesso em:17 jan. 2017.

UNITED NATIONS CONFERENCE ON TRADE AND DEVELOPMENT (UNCTAD). Creative Economy Report 2010. UNTED NATIONS, 2010.

${ }^{1}$ (Probably, from the French marqueterie) it is the art or technique of decorating the flat surfaces of furniture, panels, floors, ceilings, through the application of multiple materials, such as: wood, metals, mother of pearl, stones, plastics, ivory and animal horns. (ONLINE DICTIONARY). 